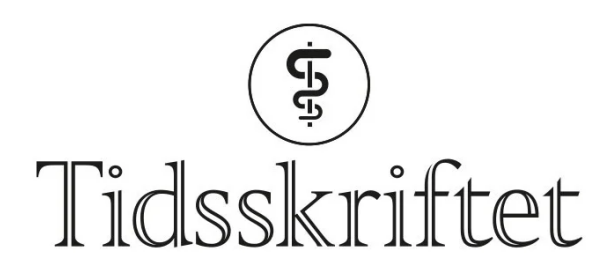

DEN NORSKE LEGEFORENING

\title{
Kunnskapsbasert praksis for pasienter med alvorlig venøs trombose
}

KOMMENTARARTIKKEL

\section{TONE ENDEN}

Tone Enden (f. 1969) er spesialist i radiologi og er for tiden postdoktor med arbeidssted Harvard School of Public Health..

Forfatter har fylt ut ICMJE-skjemaet og oppgir ingen interessekonflikter.

Email: tone.enden@medisin.uio.no

Avdeling for blodsykdommer

og

Avdeling for radiologi og nukleærmedisin

Avdeling for blodsykdommer

\section{PER MORTEN SANDSET}

Per Morten Sandset (f. 1956) er spesialist iindremedisin og i blodsykdommer og forskningsleder ved Klinikk for kreft, kirurgi og transplantasjon. Han er professor i tromboseforskning.

Forfatter har fylt ut ICMJE-skjemaet og oppgir følgende interessekonflikter: Sandset har mottatt foredragshonorar fra Nycomed og Boehringer Ingelheim.

Avdeling for blodsykdommer

Oslo universitetssykehus

\section{NILS-EINAR KLØW}

Nils-Einar Kløw (f. 1954) er spesialist i radiologi og overlege og enhetsleder ved Enhet for thorax-, karog intervensjonsradiologi. Han er professor i radiologi.

Forfatter har fylt ut ICMJE-skjemaet og oppgir ingen interessekonflikter

Avdeling for radiologi og nukleærmedisin

Oslo universitetssykehus

Ved omfattende dyp venetrombose kan tilleggsbehandling med kateterbasert trombolyse gi færre kroniske plager i beinet. Derfor mener vi at voksne med akutte tromboser i bekkenet og øvre del av låret og lav blødningsrisiko bør vurderes for denne typen behandling. 
Posttrombotisk syndrom er en kronisk tilstand som utvikles gradvis etter en dyp venetrombose. Tilstanden er karakterisert av hevelse, sprengnings- og tyngdefornemmelse, hudforandringer og i verste fall venøs sårdanning. Selv etter godt gjennomført standardbehandling med antikoagulasjon og kompresjonsstrømper utvikler minst én av fire posttrombotisk syndrom etter en proksimal dyp venetrombose, dvs. dyp venetrombose i nivå med eller ovenfor kneet $(\underline{1}, \underline{2})$. Ved dyp venetrombose som strekker seg opp i øvre del av låret eller bekkenet, er risikoen enda noe høyere (3).

Det finnes ingen kurativ behandling, men en akselerert lysering av tromben vil trolig kunne hindre utvikling av venøs dysfunksjon og dermed posttrombotisk syndrom (4.). Venøs kateterbasert trombolytisk behandling i tillegg til standardbehandlingen er derfor tatt i bruk flere steder, på tross av manglende dokumentasjon om klinisk effekt (5). Klinisk erfaring og resultater fra en rekke ikke-kontrollerte studier tyder på at behandlingen er effektiv og medfører liten blødningsrisiko (므). Det er ikke holdepunkter for $ø$ kt risiko for embolisering eller andre komplikasjoner. Ved bruk av trombolytisk agens (alteplase) med høy affinitet for fibrin oppnås en primært lokal effekt med betydelig lavere dose enn ved systemisk trombolytisk behandling (므).

Vi har i et samarbeidsprosjekt i Helse Sør-Øst gjennomført den første store randomiserte, kontrollerte studien med evaluering av klinisk relevant effekt av tilleggsbehandling med kateterbasert trombolyse (7.). Etter to år var forekomsten av posttrombotisk syndrom $56 \%$ hos dem som fikk standard behandling alene, mot $41 \%$ hos dem som fikk tilleggsbehandling med trombolyse. Studien gir også støtte til det som kalles «åpen venehypotesen», ved at venøs rekanalisering etter seks måneder forekom hyppigere i trombolysegruppen og var assosiert med lavere forekomst av posttrombotisk syndrom etter to år enn ved manglende rekanalisering $(7, \underline{8})$. Sammen med to pågående studier i Nederland og USA håper vi resultatene fører til en bedre kunnskapsbasert praksis for disse pasientene (www.clinicaltrials.gov: NCToo970619, NCToo790335).

\section{Hvem skal tilbys behandlingen?}

Det er vår mening at voksne med akutte tromboser i bekkenet eller øvre del av låret og samtidig lav blødningsrisiko bør vurderes for kateterbasert trombolytisk behandling. Hos eldre pasienter må potensiell nytteeffekt og risiko veies opp mot forventet levealder og aktivitetsnivå. Behandling av pasienter med kreft er omdiskutert, men ved ikke-avansert kreft kan kateterbasert trombolytisk behandling vurderes med samme behandlingsmål dersom det ikke foreligger redusert forventet levetid eller $\emptyset \mathrm{kt}$ blødningstendens. Ved betydelig posttrombotiske plager fra tidligere dyp venetrombose i samme bein kan ikke venøs trombolytisk behandling forventes å gjøre samme nytte.

Ved symptomvarighet over to uker øker sannsynligheten for at trombemassene er organisert og mindre mottakelige for trombolytisk medikament, og den endogene reaktive inflammasjonen kan allerede ha ført til skade på veneklaffene. Det er derfor ønskelig med rask vurdering når høy proksimal dyp venetrombose er påvist. Overføring til sykehus som tilbyr prosedyren kan da planlegges, og pasienten behandles i mellomtiden med lavmolekylært eller ufraksjonert heparin. Proksimal dyp venetrombose har rutinemessig ofte medført kort innleggelse for oppstart av antikoagulasjonsbehandling og tilpasning av kompresjonsstrømper. Tilleggsbehandling med kateterbasert trombolyse vil medføre lengre innleggelse med sengeleie under pågående infusjon, men pasientene kan mobiliseres og overføres lokalsykehus samme dag behandlingen avsluttes.

\section{Oppfølging}


Etter den trombolytiske behandlingen skal pasientene ha antikoagulasjonsbehandling i tråd med gjeldende retningslinjer samt daglig bruke knelange kompresjonsstrømper klasse II (30 mm Hg) i minst to år (4).

Det har vært ulik oppfølgingspraksis etter venøs trombolytisk behandling, også innad i Oslo-sykehusene. Enkelte har, vanligvis med ultralydbaserte metoder, kontrollert posttrombotisk venøs funksjon og morfologi. Det foreligger ikke dokumentasjon om nytten av slik oppfølging, og vi vil hevde at minst like viktig er det at alle pasienter med dyp venetrombose, uansett behandling, informeres om at de har $\emptyset \mathrm{kt}$ risiko for ny blodpropp. Dersom de etter avsluttet antikoagulasjonsbehandling får nye symptomer eller mistanke om ny dyp venetrombose, bør terskelen være lav for å kontakte lege og bli henvist til bildediagnostisk avklaring. Hos pasienter med ny trombose eller vedvarende uttalte posttrombotiske plager vil det kunne være aktuelt med ny endovaskulær behandling. Indikasjon for supplerende angioplastikk eller reintervensjon vil imidlertid neppe kunne avklares i randomiserte, kontrollerte studier, da dette vil kreve en svært stor studiepopulasjon.

Behandlingen krever tett samarbeid mellom klinikere (indremedisinere og hematologer) og radiologer. Intervensjonsradiolog etablerer venetilgang, starter infusjon av trombolytisk agens og vurderer behandlingseffekten med venografi daglig.

Det gjenstår å avklare flere tekniske forhold ved den kateterbaserte prosedyren, så som dosering av alteplase og supplerende mekanisk trombolysering. I mellomtiden mener vi at pasienter med dyp venetrombose i lår og bekken og lav blødningsrisiko bør henvises til vurdering med tanke på tillegg av kateterbasert trombolytisk behandling. Vi mener også at behandlingen primært bør gis av klinikere med spesiell interesse for pasientgruppen og av intervensjonsradiologer med erfaring med metoden.

Publisert først på nett 14.5. 2012

Publisert først på nett 14.5. 2012

\section{LITTERATUR}

1. Prandoni P, Lensing AW, Prins MH et al. Below-knee elastic compression stockings to prevent the post-thrombotic syndrome: a randomized, controlled trial. Ann Intern Med 2004; 141: 249-56. [PubMed]

2. Brandjes DP, Büller HR, Heijboer H et al. Randomised trial of effect of compression stockings in patients with symptomatic proximal-vein thrombosis. Lancet 1997;349: 759-62. [PubMed] [CrossRef]

3. Kahn SR, Shrier I, Julian JA et al. Determinants and time course of the postthrombotic syndrome after acute deep venous thrombosis. Ann Intern Med 2008; 149: 698-707. [PubMed]

4. Kearon C, Akl EA, Comerota AJ et al. Antithrombotic therapy for VTE disease: Antithrombotic Therapy and Prevention of Thrombosis, gth ed: American College of Chest Physicians Evidence-Based Clinical Practice Guidelines. Chest 2012;141 (suppl): e419S-94S. [PubMed] [CrossRef]

5. Elsharawy M, Elzayat E. Early results of thrombolysis vs anticoagulation in iliofemoral venous thrombosis. A randomised clinical trial. Eur J Vasc Endovasc Surg 2002; 24: 209-14. [PubMed] [CrossRef]

6. Vedantham S, Thorpe PE, Cardella JF et al. Quality improvement guidelines for the treatment of lower extremity deep vein thrombosis with use of endovascular thrombus removal. J Vasc Interv Radiol 2006; 17: 435-48. [PubMed] [CrossRef]

7. Enden T, Haig Y, Kløw NE et al. Long-term outcome after additional catheter-directed thrombolysis versus standard treatment for acute iliofemoral deep vein thrombosis (the CaVenT study): a randomised controlled trial. Lancet 2012;379:31-8. [PubMed] [CrossRef]

8. Enden T, Kløw NE, Sandvik L et al. Catheter-directed thrombolysis vs. anticoagulant therapy alone in deep vein thrombosis: results of an open randomized, controlled trial reporting on short-term patency. J Thromb Haemost 2009; 7: 1268-75. [PubMed] [CrossRef] 
Mottatt 16.4. 2012, første revisjon innsendt 24.4. 2012, godkjent 26.4. 2012. Medisinsk redaktør Merete K. Holtermann.

(C) Tidsskrift for Den norske legeforening 2023. Lastet ned fra tidsskriftet.no 26. april 2023. 